\title{
Should I stay or should I go? Founder's decision to leave an entrepreneurial venture during an industrial crisis
}

\author{
Stefano Colombo \\ (corresponding author) \\ stefano.colombo@unicatt.it \\ Department of Economics and Finance-Università Cattolica del Sacro Cuore di Milano \\ Luca Grilli \\ luca.grilli@polimi.it \\ Department of Management, Economics and Industrial Engineering-Politecnico di Milano
}

\begin{abstract}
We investigate if while experiencing an intensely negative industry-specific shock, skilled entrepreneurs may decide to leave the firm they founded, whereas founders who are less endowed with human capital may decide to continue their activity. Developing a stylized theoretical framework of the issue intended to derive the necessary and sufficient conditions for the emergence of this phenomenon, this study explores its occurrence in Italy during the ICT industry crisis from early 2000 to 2003 by analyzing the individual stay/leave decision of a sample of 201 founders of 79 start-ups operating in the ICT services market.
\end{abstract}

JEL classification: L26; L86; M13.

Keywords: entrepreneurial choice; stay/leave decision; high-tech entrepreneurship; adverse selection; founder human capital 


\section{Should I stay or should I go? Founder's decision to leave an entrepreneurial venture during an industrial crisis}

Rational Man's stone of Sisyphus is to think the possible, to form his values, to plan. His respite comes with the act. He observes himself, collects his rewards and punishments, and renews himself for the next intellectual struggle, the next leap of faith (Richard H. Day, 1971, p. 249)

\section{INTRODUCTION}

This article studies the relationship between an entrepreneur human capital and whether (s)he will choose to continue to work at the same firm or choose an alternative employment option when the current firm is experiencing an industry-specific crisis. Consider the following real-world example: Mr. X, after seven years of professional work experience, decides to become an entrepreneur in the information and technology services industry. He is a welleducated entrepreneur with a $\mathrm{PhD}$ in computer science, he holds $30 \%$ of the shares of a company specialized in professional Web marketing services. He cofounded the company in 1999, before the tech-stock bubble burst in the fall of 2000, and subsequently the whole industry entered into a gloomy crisis. During the unfolding of the crisis, Mr. X faces the following dilemma. On one hand, he may take a persistence decision by going on with the firm he founded. After all, he believes in his skills, and he is confident of obtaining quite high profits, even during the industry specific crisis. However, he is also tempted to leave the firm to find an alternative job: for example, being a salaried worker. Since he has a high level of human capital, his alternative options are likely to be attractive. At the end, in the year 2002, Mr. X leaves the firm and opts to work as a salaried employee in another firm. He will never take the entrepreneurial path again in his career, and he will later become a manager in a company specialized in developing software for the food industry. 
As the example above has shown, from a pure theoretically rational perspective, the impact of entrepreneur human capital on the decision to "stay" or "leave" is controversial. On the one hand, an educated and skilled entrepreneur is more likely than an uneducated and unskilled one to obtain higher returns in the sector in which the crisis occurs (e.g. Unger et al., 2011), and therefore, all else being equal, an entrepreneur with a large amount of human capital should be less inclined to jump out of the firm in question during the industry crisis. On the other hand, for entrepreneurs who have a high level of human capital, the opportunity costs of running the firm during the crisis may be high given the potential returns on their efforts in alternative areas, and this might make entrepreneurs with high human capital more likely to look for other employment opportunities (e.g. Amit et al., 1995). Therefore, it is possible that during an industry-specific crisis, relatively highly educated and skilled entrepreneurs stop running the firm, whereas entrepreneurs with a low human capital profile continue operations; the former have more attractive alternative options, whereas the latter are locked into their venture because they do not have access to valid alternative opportunities. ${ }^{1}$ From an empirical point of view, the literature on the determinants of new venture survival reflects these opposite forces to some extent. The general contention and prevalent view is that the entrepreneur's human capital positively affects the continuation of firm operations (e.g. Delmar and Shane, 2006; Santarelli and Vivarelli, 2007, Dahl and Reichstein, 2007), but the available evidence reveals more than one exception (Bates, 1989; Cressy, 1996; Storey and Wynarczyk, 1996; Shane and Stuart, 2002; Grilli, 2011; Coad et al., 2013; Criaco et al., 2014. See also the recent, albeit not exhaustive, review by Gimmon and Levie, 2010).

\footnotetext{
1 According to the Global Entrepreneurship Monitor (GEM) Observatory, approximately one-third of the entrepreneurs in modern advanced economies can be defined as "necessity entrepreneurs"; i.e., individuals who have become entrepreneurs because they have no other viable choice of occupation (Parker, 2009). Evans and Leighton (1989) were among the first ones to document the numerical importance of this typology of entrepreneurs among young U.S. self-employed individuals.
} 
When the phenomenon of the exit of high human capital entrepreneurs is numerically relevant, the industry crisis produces a perverse effect in the selection mechanism of the entrepreneurs that may exert negative consequences on the static and dynamic efficiency of the market. This may lead to an adverse selection situation where the entrepreneurs with high human capital are more likely than the entrepreneurs with low human capital to exit as a consequence of an industry crisis. We are not the first to recognize the possible emergence of adverse selection phenomena in entrepreneurial dynamics (see, for example, Cumming, 2006, on the matching between typologies of financiers and entrepreneurs), and we are not alone in the literature on entrepreneurship in emphasizing the possible arising of the specific adverse selection event analyzed here. In fact, the idea was first suggested by Gimeno et al. (1997, p.756; see also McGrath 1999, p. 14; and among the others, Headd 2003, DeTienne et al. 2008). In a nutshell, high-profile human capital characteristics may raise the opportunity costs of running a firm during an industry crisis because the entrepreneur may receive higher returns from switching to an alternative occupation, and this may actually encourage the exit of skilled, rather than unskilled, entrepreneurs from an industry experiencing negative shock.

Although this topic is relevant to our understanding of the drivers of the dynamic efficiency of economic systems, the theoretical research addressing the possibility of adverse selection phenomena during an industry crisis is quite scarce. Holmes and Schmitz (1990 and 1995) adopt a matching model between firms and founders characterized by different endowments of entrepreneurial ability in order to determine the rate of entrepreneurial exit. The main finding is that the probability of entrepreneurial exit is higher when the match is poor. More recently, Arora and Nandkumar (2011) build a model where the entrepreneur may do a costly investment to augment the quality of the firm, in order to increase the probability of a profitable cash-out in a subsequent period. However, this may also increase the risk of a firm's failure. The authors 
find that high-quality entrepreneurs invest more, thus having both a higher hazard of a cash-out and a higher risk of failure than low-quality entrepreneurs.

Moreover, the extant empirical literature has mainly concentrated its attention on the relationship between founder human capital and entrepreneurial survival at firm level, leaving aside the micro-perspective of the individual decision to continue working in the firm (s)he founded or abandon it (for a similar point of view see e.g. Stam et al., 2010; DeTienne and Cardon, 2012). In this latter area, most of the received knowledge relates to studies using macropanel datasets on self-employment transitions (e.g. U.S. Panel Study of Income Dynamics, i.e. PSID, U.S. Longitudinal Survey of Youth, British Household Panel Survey) or refers to analyses that are both firm- and individual-level at the same time, being based on solely singlefounded firms (e.g. Wennberg et al., 2010). ${ }^{2}$ In line with the firm-level empirical literature mentioned above, some of these studies point steadily towards a negative relationship between individual's human capital attributes and entrepreneurial exit (e.g. Bruce, 2002; Burke et al., 2008), but again also in this stream of literature, there are remarkable exceptions that do not find strong statistically significant relationships between the two investigated dimensions (e.g. Schiller and Crewson, 1997; Taylor, 1999; Van Praag, 2003; Schäfer and Talavera, 2009).

Grounding on this received background, the present study is intended to add to the entrepreneurial decision-making literature in two important aspects. First, we develop a simple stylized micro-founded framework addressing the issue of adverse selection in entrepreneurship as a consequence of agents' utility-maximizing behavior (see, for example, Hundsdoerfer and Sichtmann, 2009) during an industry-specific crisis. In particular, the key features of the model are the following. There are many types of agents, where each type is identified by the human

\footnotetext{
${ }^{2}$ There also exist in the literature other studies that in the same vein as Wennberg et al. (2010) position themselves in-between an individual-and firm-level survival analysis. The recent work of DeTienne and Cardon (2012) represents an example. Here, the authors investigate the impact of founder human capital measured at individual level on the preferred prospective ways of exit for the firms these founders created. Their analysis highlights how different founders' characteristics in terms of experience exert a differential impact on the modes of entrepreneurial exit.
} 
capital level. For each type, there is a continuum of agents, each of them endowed with a different level of entrepreneurial ability. Each agent has to decide whether to be an entrepreneur or choosing an alternative option (i.e. being a salaried worker). The agent chooses the option that gives her the higher utility. In such a context we suppose that a negative shock hits the industry (i.e., we suppose that an industry crisis occurs), by affecting the expected profits in the industry as well as the alternative options, and we define the necessary and sufficient condition for the high human capital entrepreneurs being more likely than the low human capital entrepreneurs to leave the entrepreneurial venture.

Secondly, we explore the realism of adverse selection in entrepreneurship from an empirical point of view, by focusing on the ideal test-bed represented by the ICT sector in the decade centered around the year 2000, with macro-economic dynamics showing a sectorial boom, immediately followed by a bust period. More specifically, we analyze the individual stay/leave decision on a main sample of 201 founders of 79 Italian ICT services co-founded start-up companies during the specific telecom and dot.com stagnation that occurred between early 2000 to 2003. ${ }^{3}$ Start-ups were created during the ICT boom period from 1995 to early 2000. These firms were still active as independent entities at the beginning of year 2004, so the individual decision of stay/leave that we analyze is purely individual and not driven by other possible confounding factors at firm-level, i.e. the collective (forced or not) decision to close operations or accept eventual buying offers from other firms. ${ }^{4}$ The results document the potential relevance of adverse selection in this specific context but at the same time they enrich our understanding

\footnotetext{
${ }^{3}$ For an analogous periodization (and description) of the telecom boom and bust, see Fransman (2004) and Kam (2006). Note that the findings that will be presented later are rather insensitive to a more stringent definition of the burst period (i.e., from 2001 to 2003).

${ }^{4}$ We also execute an additional analysis (See Section 6.2) on an enlarged sample of individuals including those whose firm failed or was acquired during the bust period early 2000-2003 and those individuals who were single founders and not part of a founding team. In this respect, note that Grilli (2011) performed a similar analysis on the same time span here analyzed but based on firm-level data and highlighted how different levels and typologies of human capital collectively possessed by the founding teams could differently shape an ICT services firm's exit dynamics.
} 
of entrepreneurial decision-making in turbulent times, by identifying specific human capital drivers of the stay/leave decision. Indeed, they show that a relatively higher level of human capital endowment actually encouraged the entrepreneurs to leave the entrepreneurial start-up during the industry-specific recession.

More specifically, by estimating econometric models of individual stay/leave decision of a founder from the original entrepreneurial team during an industry crisis, we find that both the level of education and the work experience have a significant and positive effect on the likelihood that entrepreneurs sell their participation stakes and leave the firm during the industry-specific crisis. Interestingly, the impact of work experience on the likelihood of exit remains positive, both when it has been gained in the same sector where the crisis occurs and when it has been gained in other sectors. The only exception is represented by the managerial experience, as we find that higher managerial experience tends to reduce the likelihood of entrepreneurial exit.

Our results have relevant implications for entrepreneurship research. Indeed, in contrast with existing literature, the present paper focuses on the stay/leave decision of a founder during an industry-specific crisis. The adoption of this approach allows highlighting the potential existence of a relevant adverse selection phenomenon which has been almost neglected by the literature. Indeed, when the entrepreneurial exit from an industry sector mainly involves high human capital entrepreneurs (as we documented for the Italian ICT sector), there are two sources of efficiency loss. The first one is a sectorial loss of efficiency. Indeed, if well-educated and skilled entrepreneurs leave the firm they have founded after few years from the foundation, they cannot effectively imprint with their vision and values the firm they have created, thus reducing the set of capabilities of the entrepreneurial ventures they created. The second loss of efficiency is more subtle, but not less relevant. Indeed, business ideas, especially those regarding newly created firms, are often highly associated with the founder: therefore, if the 
founder leaves, such business ideas may not materialize. This may be a significant source of reduction of the dynamic efficiency of the whole economic system. ${ }^{5}$

The structure of the article is as follows. Section 2 analyzes the individual stay/leave decision of an entrepreneur experiencing an industry crisis and introduces a stylized framework to derive a necessary and sufficient condition for the arising of adverse selection phenomena in entrepreneurs' human capital. Section 3 presents the background for the empirical analysis. Section 4 describes the data. Section 5 outlines the econometric specification. Section 6 reports the results of the econometric analysis. Section 7 concludes and contains implications emerging from our analysis.

\section{A STYLIZED FRAMEWORK}

In what follows, we propose a simple theoretical framework to investigate the effects of a crisis arising in industry $i$ on the decision of an individual (the agent, henceforth) endowed with human capital who faces the dilemma of continuing to work in the firm (s)he has founded (being an entrepreneur in industry $i$, henceforth) or choosing an alternative option (for example, being a salaried worker in the same sector or being a salaried worker or an entrepreneur in a different sector).

Suppose that exist $E$ types of agents, indexed with $e=1,2, \ldots, E$, where $e$ defines the human capital level. In particular, we assume that the higher $e$ is, the higher is the level of human capital an agent is endowed with. There is a continuum of agents for each type-e, whose distribution is given by $f_{e}\left(x_{e}\right)$, with $x_{e} \in\left[\underline{x}_{e}, \bar{x}_{e}\right]$, where $x_{e}$ indicates the entrepreneurial ability of the specific type-e agent $x$. We assume that $\underline{x}_{e^{\prime}} \geq \bar{x}_{e} \forall e^{\prime}>e$. This implies that those agents that are endowed with a higher human capital have also higher entrepreneurial ability. ${ }^{6}$ Let us

\footnotetext{
${ }^{5}$ For a wider discussion of the implications of our results, see the discussion in Section 7.

${ }^{6}$ Clearly, this assumption may be not valid in some industries. For example, in the case of the biotechnology sector the individuals with the highest human capital may be scientists with low entrepreneurial experience and managerial skills. However, the Italian ICT sector (which constitutes the test bed of the subsequent econometric
} 
assume that the characteristics of the economic scenario in sector $i$ are captured by a single parameter, $\gamma$. In particular, we assume that the higher is $\gamma$, the worse is the economic situation of sector $i$. Consequently, we say that when $\gamma$ increases an industry crisis occurs, that is the economic situation in sector $i$ deteriorates. $^{7}$ The profits of entrepreneur $x_{e}$ in industry $i$ are described by the following separable function: $\pi_{x \mid e}\left(x_{e}, \gamma\right)=v_{e}\left(x_{e}\right)-k_{e}\left(x_{e}, \gamma\right)$. The first term is positive and it is affected positively by the level of human capital. The second term is also positive and it is affected positively by $\gamma$. Therefore, when there is an industry crisis (i.e. when $\gamma$ goes up), all else being equal the profits decrease. In particular, let $\rho_{e} \equiv \frac{\partial k_{e}}{\partial \gamma} \geq 0$ denote the profits' sensitivity to variations of the economic situation: the profits decrease during an industry crisis. $^{8}$

Let $w_{e}(\gamma)$ denote the value of the best alternative option for a type-e agent. This alternative option may be, for example, being a salaried worker in the industry $i$, or being an entrepreneur or a salaried worker in a different industry. ${ }^{9}$ Denote by $\alpha_{e} \equiv \frac{\partial w_{e}}{\partial \gamma}$ the sensitivity of the value of the type- $e$ best alternative option to variations of the economic situation. The sign of $\alpha_{e}$ is in principal ambiguous. If the best alternative option consists in being a salaried worker in industry

analysis) has been characterized by massive entry during the boom period, which seems to be consistent with the existence of low entry barriers and the small incidence of star scientists on entry rates. Therefore, our assumption seems reasonable for this industry. Formally, this means that the distribution of two different types does not overlap.

${ }^{7}$ Note also that the analysis is focused on an industry-specific crisis, i.e. a crisis that arises in a specific sector of the economy.

${ }^{8}$ Formally, the first term of the profits function, $v_{e}$, increases with $x_{e}$. Moreover, $v_{e^{\prime}}>v_{e}, \forall e^{\prime}>e$. Also, note that $k_{e}$ (.) depends on the entrepreneurial ability of the agent, $x_{e}$. Let us assume that $\partial k_{e} / \partial x_{e} \leq 0$. This guarantees that the profits increase with human capital and/or entrepreneurial ability of the agent at any economic scenario. Furthermore, note that $\rho_{e}$ may be also function of $x_{e}$.

${ }^{9}$ If the best alternative option is to be an entrepreneur in an industry different from $i$, the value of this option depends both on the human capital and the entrepreneurial ability of the agent. That is, it should be: $w_{e}\left(x_{e}, \gamma\right)$. This case can be analysed as the simpler situation described in the text: details are available on request. 
$i, \alpha_{e}$ decreases with $\gamma$. Indeed, the salaries in industry $i$ are expected to weakly decrease when a crisis occurs. On the other hand, a crisis arising in industry $i$ affects also other industries. This creates a second-order effect on both the salaries and the profits in those industries. Such effect may be positive or negative. For example, if industry $j \neq i$ produces a complement good of the good produced in industry $i$, the crisis occurring in industry $i$ is likely to negatively affect the profits and the salaries in industry $j$, whereas the opposite (disregarding the wealth effect) is expected in the case where the good produced in industry $j$ is a substitute of the good produced in industry $i$. Hence, if the best alternative option consists in being a salaried worker or an entrepreneur in industry $j \neq i, \alpha_{e}$ might decrease or increase with $\gamma$.

Each type-e agent has to decide whether to be an entrepreneur in industry $i$ or choose the best alternative option. ${ }^{10}$ (S)he chooses to be an entrepreneur in industry $i$ if the profits are higher than the value of her/his best alternative option (Becker, 1975; Evans and Jovanovic, 1989; Bates, 1995). Denote by $\hat{x}_{e}$ the marginal type-e agent, which can be defined as the type$e$ agent who is indifferent between being an entrepreneur in industry $i$ or choosing the best alternative option. Therefore, the marginal type-e agent is the solution of the following equation:

$$
\pi_{x \mid e}\left(\hat{x}_{e}, \gamma\right)=w_{e}(\gamma)
$$

It follows that all type-e agents such that $x_{e} \in\left[\hat{x}_{e}(\gamma), \bar{x}_{e}\right]$ maximize their utility by choosing to be entrepreneurs, while all type-e agents with $x_{e} \in\left[\underline{x}_{e}, \hat{x}_{e}(\gamma)\right]$ prefer not to be entrepreneurs

\footnotetext{
${ }^{10}$ We do not consider the case where an agent diversifies her/his activities (for example, running a firm while parttime working as a salaried worker for another firm). Our dataset does not contain this information in a systematic way, and this is a limitation of our study. However, qualitative information we collected through interviews with firms' owner-managers suggests the absence of numerically relevant hybrid activities among the Italian high-tech entrepreneurs surveyed. For an empirical analysis on hybrid entrepreneurship see Folta et al. (2010). See also Li et al. (2006) regarding the involvement of entrepreneurs in (political) activities other than simply running their firms.
} 
by choosing the best alternative option. Therefore, the number ${ }^{11}$ of type-e entrepreneurs in industry $i$ is given by:

$$
I_{e}=\int_{\hat{x}_{e}(\gamma)}^{\bar{x}_{e}} f_{e}(x) d x
$$

Let $F_{e}$ be the primitive of $f_{e}\left(x_{e}\right)$ in the support $\left[\hat{x}_{e}(\gamma), \bar{x}_{e}\right]$. Then: $\partial F_{e} / \partial x_{e}=f_{e}\left(x_{e}\right)$, $\forall x_{e} \in\left[\hat{x}_{e}(\gamma), \bar{x}_{e}\right]$. The number of type-e entrepreneurs in industry $i$ can be rewritten as:

$$
I_{e}=F_{e}\left(\bar{x}_{e}\right)-F_{e}\left(\hat{x}_{e}(\gamma)\right)
$$

Therefore, the impact of an industry crisis on the number of type-e entrepreneurs in industry $i$ is captured by the derivative of (3) with respect to $\gamma$, that is:

$$
\frac{\partial I_{e}}{\partial \gamma}=-f\left(\hat{x}_{e}\right) \cdot \frac{\partial \hat{x}_{e}\left(\alpha_{e}, \rho_{e}\right)}{\partial \gamma}
$$

The sign of (4) establishes whether the number of type-e entrepreneurs in industry $i$ increases or decreases after a negative shock in industry $i .{ }^{12}$ As the sign of (4) depends on the sign of $\frac{\partial \hat{x}_{e}}{\partial \gamma}$, we have the following: if $\frac{\partial \hat{x}_{e}}{\partial \gamma} \geq 0$, the marginal type-e agent is higher after the crisis, and the number of type-e entrepreneurs decreases; if $\frac{\partial \hat{x}_{e}}{\partial \gamma} \leq 0$, the marginal type-e agent is lower after the crisis, and the number of type-e entrepreneurs increases.

\footnotetext{
${ }^{11}$ We use the term "number" for expositional simplicity, but since there is a continuum of individuals we mean "measure".

${ }^{12}$ As the framework is purely micro-founded, an increase of the number of entrepreneurs may mean that new firms are founded, or that some previously non-entrepreneur agents participate with own shares in previously founded firms. Similarly, a reduction of the number of entrepreneurs may imply that some founders leave the firms they have founded (but the firms still exist), or that some firms close (when all founders leave, or the firm has a single founder and the founder exits). The empirical analysis in the next sections is primarily based on co-founded firms that were still alive after the exit of one of the founders (see later in Section 4 for details and a theoretical justification of this approach), but evidence is also provided by enlarging the focus on exited firms and singlefounded start-ups (see Section 6.2).
} 
To investigate the sign of $\frac{\partial \hat{x}_{e}}{\partial \gamma}$, it may be useful to define the following function: $L_{e}(x, \gamma) \equiv w_{e}(\gamma)-\pi_{x \mid e}\left(x_{e}, \gamma\right)$. Note that (1) implies $L\left(\hat{x}_{e}, \gamma\right)=0$. Hence, $\frac{\partial \hat{x}_{e}}{\partial \gamma} \geq(\leq) 0$ if and only if $\frac{\partial L_{e}}{\partial \gamma} \geq(\leq) 0$. Therefore, we can sum up as follows the necessary and sufficient condition for a decrease of the number of type-e entrepreneurs (condition C1):

C1) The necessary and sufficient condition for a decrease of the number of type-e entrepreneurs is: $\frac{\partial L_{e}}{\partial \gamma} \geq 0$

Condition C1 basically says that when $\frac{\partial L_{e}}{\partial \gamma} \geq 0$, the indifferent type-e agent is located more to the right along the support $x_{e} \in\left[\underline{x}_{e}, \bar{x}_{e}\right]$. It follows that fewer type-e agents choose to be entrepreneurs rather than choosing the alternative option. Note that the derivative of $L_{e}$ with respect to $\gamma$ is:

$$
\frac{\partial L_{e}}{\partial \gamma}=\frac{\partial w_{e}}{\partial \gamma}-\frac{\partial \pi_{x \mid e}}{\partial \gamma}=\alpha_{e}-\left(-\frac{\partial k_{e}}{\partial \gamma}\right)=\alpha_{e}+\rho_{e}
$$

As $\rho_{e} \geq 0$ by assumption, it follows that, if $\alpha_{e} \geq 0, \hat{x}_{e}$ always increases with $\gamma$, and the number of type-e entrepreneurs diminishes. Instead, if $\alpha_{e} \leq 0, \hat{x}_{e}$ increases with $\gamma$ if and only if $\rho_{e} \geq\left|\alpha_{e}\right|$. In other words, the number of type- $e$ entrepreneurs in industry $i$ diminishes after an industry crisis if and only if the sensitivity of the profits of the marginal type-e agent to variations of the economic situation, $\rho_{e}$, is higher (lower) than the sensitivity of the type-e best alternative option, $\alpha_{e}$. 
In what follows, we assume that the sign of $\frac{\partial \hat{x}_{e}}{\partial \gamma}$ is the same for all types of agents. ${ }^{13}$ Also, we suppose that condition C1 holds. We are now in the position to formalize the necessary and sufficient condition for the occurrence of adverse selection in the human capital of entrepreneurs as a consequence of an industry crisis. Recall that adverse selection requires that the decrease of the number of type-e entrepreneurs induced by a negative shock is smaller (larger) than the decrease of the number of type- $e^{\prime}$ entrepreneurs if $e^{\prime} \geq(\leq) e$. That is, we have adverse selection in the human capital of entrepreneurs when the higher is $e$ (i.e. the higher is the human capital of entrepreneurs), the more likely is their departure from the founded startup. Therefore, the necessary and sufficient condition for the occurrence of adverse selection in the human capital of entrepreneurs can be expressed as follows (condition C2):

C2) Suppose that C1 holds. The necessary and sufficient condition for the occurrence of adverse selection in the human capital of entrepreneurs is: $\frac{\partial^{2} L_{e}}{\partial \gamma \partial e} \geq 0$.

Using (5), condition C2 can be restated as $\frac{\partial^{2} L_{e}}{\partial \gamma \partial e}=\frac{\partial\left(\rho_{e}+\alpha_{e}\right)}{\partial e} \geq 0$. In other words, the necessary and sufficient condition requires that the sum of the impact of a negative shock on the profits and the impact of the same shock on the best alternative option increases with the human capital of the agent. Hence, while condition C1 is the necessary and sufficient condition for a negative shock to reduce the number of the entrepreneurs of a specific type of entrepreneurs, condition C2 is the necessary and sufficient condition for the reduction of type$e$ entrepreneurs being an increasing function of $e$, that is, for the arising of adverse selection phenomena in the human capital of entrepreneurs caused by a negative industry-specific shock.

\footnotetext{
${ }^{13}$ Formally, this requires that $\rho_{e} \geq(\leq)\left|\alpha_{e}\right| \Leftrightarrow \rho_{e^{\prime}} \geq(\leq) \mid \alpha_{e^{\prime}}$, with $e \neq e^{\prime}$. That is, if the sensitivity of the profits of the marginal type-e agent to the economic situation is higher than the sensitivity of the best alternative option, the same must hold for any other type. It is worth noting that this is not necessary for adverse selection to occur, but it allows deriving an easily interpretable necessary and sufficient condition for adverse selection (see later).
} 
Note that our model can be easily adapted also to the case of an industry boom. In particular, if $\gamma$ decreases an industry boom occurs. In such situation, adverse selection in entrepreneurship may arise when agents with lower human capital are more likely to become entrepreneurs. In this case, condition C2 would imply that the sum of the impact of a positive shock on the profits and the impact of the same shock on the best alternative option decreases with the human capital of the agent. ${ }^{14}$

The predictions of our framework can be summarized in Table 1, where the likelihood of entry (vs. stay out) and the likelihood of leave (vs. stay in) of individuals with different levels of human capital is described for different industry conditions.

\section{[Table 1]}

In the next sections, we will empirically document the realism of such phenomena, by analyzing the individual stay/leave decision of a sample of founders of Italian ICT services start-up companies during the crisis that hit the sector from early 2000 to $2003 .^{15}$

\section{TEST-BED FOR THE EMPIRICAL ANALYSIS}

We investigate if and to what extent an industry-specific crisis may encourage high human capital entrepreneurs to leave their venture and for which dimensions of human capital this is more likely by taking advantage of an impetuous upside down experienced by a single sector with respect to the whole economic system: the boom and bust period of the ICT sector around the year 2000. This represents an ideal testing ground in order to investigate the potential relevance of the adverse selection phenomenon. First, ICT is a general-purpose technology that

\footnotetext{
${ }^{14}$ However, it should be noted that in the case of entry, there would be other factors affecting the decision of an agent. Indeed, as noted by Holland and Garret (2015), a persistence decision (i.e. whether to stay or leave) is different from a start-up decision (i.e. whether to enter or stay out), as the former entails less uncertainty than the latter. This aspect is not considered in the present model.

${ }^{15}$ Note that the model we proposed is based on the individual decision of an agent. This allows considering the relative likelihood of exit among individuals of higher versus lower human capital both within a firm and across firms. This is consistent with our sample (see the subsequent sections), where we have both homogeneous firms (where all the entrepreneurs are endowed with the same level of human capital) and heterogeneous firms (where the entrepreneurs have different levels of human capital).
} 
is ubiquitous in many sectors of the economy. Unlike other typologies of sectorial experience, skills and competencies developed in ICT are likely to have a broader scope and could probably be applicable far beyond ICT and strictly related industries (Bresnahan and Trajtenberg, 1995). Secondly, the ICT boom was characterized by an enormous and to some extent irrational euphoria that led to the birth of a great number of start-ups that entered the sector with high and often unrealistic expectations (Fransman, 2004). Third, the bust period was intense, and although it obviously affected the entire economy, it was also confined to some extent to ICT and related sectors, whereas it spread with less virulence to the rest of the industries. Specifically, the Italian average GDP annual growth rate was $1.74 \%$ in the ICT boom period 1995-1999 and 1.5\% in the bust period 2000-2003 (source: Eurostat) suggesting how the rest of the Italian economy experienced almost a constant performance throughout the ICT boom and bust periods.

Conversely, between 1995 and early 2000, the ICT sector experienced a dramatic boom: the worldwide ICT growth rate during this period registered an average increase of approximately $10 \%$ per year (EITO, 2004). Starting in mid-2000, the sector entered a serious period of recession, registering a global annual growth rate of $2.7 \%$ in 2001 and $-0.4 \%$ in 2002 . This period was followed by very weak dynamics, with a growth rate of $0.8 \%$ in 2003 (EITO, 2004). The Italian ICT sector well adhered to the worldwide figures, i.e. from the peaks of the boom period, the annual growth rate fell to $-0.5 \%$ in 2002 and then recorded only a $+0.1 \%$ in 2003 (Assinform, 2006).

As highlighted by our theoretical model, the key requisite for the insurgence of the adverse selection in the human capital of entrepreneurs is that the sum of the impact of a negative shock on the profits and the impact of the same shock on the best alternative option increases with the human capital of the agent (see condition C2, p. 13). On an empirical ground, this is more likely to happen, the higher is the industry-specificity of the negative shock compared to the global 
trend of the economy, because if this is case, the higher the likelihood that entrepreneurs with high human capital will opt for alternatives and leave the start-up. As suggested by the data reported above, the Italian ICT sector during the time early 2000-2003 frame should represent quite a good candidate for the occurrence of the adverse selection phenomenon here depicted.

\section{DATA}

In the first place, we consider a sample of 201 founders (i.e. owners with an active role in the newly created start-up) of 79 Italian ICT start-up companies that operate in service industries: multimedia content, software, Internet services (e-commerce, ISP, web-related services), and telecommunication services. Sample firms were established during the boom period (between 1995 and the first quarter of 2000) and were independent at start-up time (i.e., they were not controlled by another business organization) and have remained so up to 2004 . The sample of founders of ICT start-up firms was composed by all complete individual-level information available on these firms in the RITA (Research on Entrepreneurship in Advanced Technologies) database in 2004. The RITA database developed by Politecnico di Milano represented at that time the most complete information sources available on Italian new technology-based firms (NTBFs); for a detailed description of the database and the procedure used to gather the data, see Colombo et al. (2004), Colombo and Grilli (2005) or (2013). The primary source of information from which RITA data were collected was a series of national surveys administered in the first semesters of the years 2000, 2002 and 2004. Data on sample

founders and their firms came from the first round. The survey was based on a questionnaire sent to owner-managers of target firms, either by fax or by e-mail. The first section of the questionnaire provides detailed information on the human capital characteristics of the firm's founders. The second section was composed of further questions concerning the characteristics of the firm, including their year of foundation, the number of employees along time, their financial structure, i.e. eventual access to bank debt at foundation or to VC financing before 
1999. Trained personnel checked the answers to the questionnaire for internal coherence and compared them with information published in annual reports (for example, for the number of employees) and in the press. Data on firm's employees and venture capital investments were also cross-checked with information from secondary information sources (the AIDA, the Italian fine-grained version of the Amadeus-Bureau Van Dijk database, and the VentureXpert database, respectively). In several cases, phone or face-to-face follow-up interviews were conducted with owner-managers to obtain missing data and ensure that the data were reliable.

Data on sample founders' eventual exit between the second quarter of 2000 and 2003 were gathered in the second and third round of questionnaires in 2002 and 2004 directly from the survey respondents (other founders or new owner-managers entered in the firm), verified by triangulation with the official documentation provided by the Union of Italian Chambers of Commerce (UICC), and in particular by the dataset Telemaco, ${ }^{16}$ and also by authors' inspection of popular specialized professional social network websites (e.g. LinkedIn).

The 79 firms on which our sample of 201 founders is based were all still active as independent firms up to 2004, i.e. we excluded from the analysis those firms that ceased operations or were acquired by other firms in the bust period. This way, we avoid that other than individual factors like firm's financial conditions or the possible existence of buying offers for the start-up from other established companies interfere in the individual stay/leave decision and misleadingly influence our results at the individual level. Note also that for the same reason, all sample firms are non-single founded. ${ }^{17}$ Thus, unobserved heterogeneity at firm-level is limited $^{18}$ and notably for each individual exit of a founder from a firm we have the proper

\footnotetext{
${ }^{16}$ This institution registers all business activities on the basis of fiscal codes and provides (upon payment request) eventual exit information on firms and entrepreneurs over time.

${ }^{17}$ We also excluded from the analysis those few founders who exited the start-up before the end of the boom period, because our aim is to analyze the stay/leave founder's decision during an industrial crisis. If one may suspect that some founders could have anticipated the arrival of the crisis before its beginning, note that the inclusion in our empirical analyses of the four founders exited in 1999, leave our findings totally unaltered.

${ }^{18}$ On the need of controlling in empirical entrepreneurial studies with appropriate sample choices on the inherent great amount of unobserved heterogeneity at a upper level (in our case at firm-level) with respect to the unit of
} 
counterfactual of one or more entrepreneur that in the same firm took the opposite decision and stayed on board. We do consider this restricted sample our preferred test-bed for the reasons aforementioned, and accordingly label it as "main sample"; nonetheless we also employ the “enlarged sample” of 266 founders (including exited firms and/or single-founded start-ups) in Section 6.2. on the "Robustness checks and additional evidence" in order to further validate our results and deepen our understanding of the dynamics of interest. Overall, $10 \%$ of the entrepreneurs in the main sample exited the created venture, and $20 \%$ of the start-ups experienced the leave of at least one member of the founding team over the bust period early 2000-2003. Considering the enlarged sample of 266 entrepreneurs, 30\% of them left the startup, because of an individual exit from a still surviving firm (8\%); or because the firm ceased operations (8\%); or finally, because the firm was acquired by another company (14\%).

\section{SPECIFICATION OF THE ECONOMETRIC ANALYSIS}

We estimate probit models of individual stay/leave decision of a founder from the original entrepreneurial team during the bust period with respect to his/her level of human capital. The dependent variable takes a value of 1 if the founder left during the bust period, 0 otherwise. The independent variables for founder human capital include educational attainment (Education), measured by the number of years of education of the founder; pre-entry work experience (Work experience) measured by the number of years of professional experience of founders before firm foundation, where we further distinguish between pre-entry work experience gained in the same sector of the start-up (Specific work experience) from the pre-entry work experience gained in other sectors (Generic work experience); and managerial experience (Managerial experience), measured by a dummy variable that equals 1 if the founder before foundation had a previous high managerial position in another company. At founder-level, we also control for

\footnotetext{
analysis and core of the investigation (individual-level decision making in our context) see among others,
} Wennberg et al. (2010, p. 366-367). 
the percentage of shareholdings possessed by the founder at foundation (Share founder). In fact, one might suppose that the entity of interest at stake might intervene in the individual decision, with the holding of a small (large) portion of shares leading a founder to ease (hamper) exit. This variable was collected through official sources (database Telemaco, source: UICC). Also at founder-level we insert a dummy variable capturing the gender of the individual, since gender differences do have an impact on entrepreneurial dynamics in general (e.g. Arum and Muller, 2004; Allen and Langowitz, 2011) and, more specifically, may also intervene in entrepreneurial exit patterns (Wennberg, 2012). Accordingly, Female equals one if the sex of that founder is female. Then, we add to the specification a series of firm-specific control variables. First, we control for the size of the founding team (Founders). Additionally, closely following the empirical literature on firm survival and top management team changes in entrepreneurial ventures, the models include firm size measured in terms of the logarithm of employees at the end of 1999 (Size), ${ }^{19}$ firm age (Age) and firm's access to external sources of financing at startup time (Bank debt). We also add a variable $(V C)$ that is equal to one for firms that obtained a venture capital financing from their foundation up to the end of 1999. In fact, venture capital operators are "hands-on" investors and often require changes in the composition of top management team. Thus, if proper control for the VC-backed status of firms is absent, the individual decision of the founder to stay/leave could be distorted by the conditions and potential diktats imposed by the venture capitalist to the investee company. ${ }^{20}$ Finally, the model specification includes industry and geographical controls: an industry dummy variable

\footnotetext{
${ }^{19}$ Employment is frequently used as a proxy for firm size in firm survival studies (see, e.g., Mata et al., 1995). Different measures such as total assets (e.g., Agarwal and Audretsch, 2001) or physical output (e.g., Thompson, 2005) are less common. Note that the use of the total amount of capital at foundation as an alternative measure of firm size yields very similar results (available upon request from the authors) to those presented in the next paragraph.

${ }^{20}$ Hellmann and Puri (2002) document that VC investors favor the recruitment of external managers, thus contributing to their managerial "professionalization," Bottazzi et al. (2008) show that European VC firms helped portfolio companies in recruiting outside directors and senior managers in $40.8 \%$ and $48.4 \%$ of the deals they analyze, respectively. See also Schäfer et al. (2004).
} 
(Internet) identifies start-ups active in Internet services (e-commerce, ISP, web-related services); a composite index (Infrastructure) measures the level of infrastructure and resources development in the province (NUTS 3 level) of firm's location ${ }^{21}$ and three macro-regional dummies (South, Centre, North-West where location in North-East is the benchmark) capture the remaining existing geographical heterogeneity. ${ }^{22}$

Upon the firm-specific independent control variables above reported, we also take into account the non-independence of error terms across founders of the same firm and, more generally, other possible unobserved firm-specific effects which may influence the founders' decision of stay/leave. First, a probit model was estimated by clustering founders’ individual disturbances terms on the firm dimension. Second, we estimate a probit model with random effects. $^{23}$

The definitions of the explanatory variables is reported in Table 2. Table 3 illustrates some descriptive statistics on the independent variables (on both the main and the enlarged samples), where the "stayers” and “leavers” categories are further specified. Basically, a slightly higher human capital level is generally associated to leavers rather than stayers for both samples and for most of the attributes here considered (specific work and managerial experience in the main sample are the only two notable exceptions), even if all these differences are hardly significant from a statistical point of view. Looking at more general figures, only roughly $15 \%$ of entrepreneurs are female, and on average each individual entrepreneur holds slightly more than

\footnotetext{
${ }^{21}$ The covariate provided by the National Association of Italian Companies (Centro Studi Confindustria) refers to 1992 and it is calculated as the average of a series of indexes: per capita value added, share of manufacturing out of total value added, employment index, per capita bank deposits, automobile-population ratio, and consumption of electric power per head.

${ }^{22}$ Controlling for the role of founders after their exit from the venture would also be an important feature of the econometric analysis. Unfortunately, the current dataset does not include systematically this information. We acknowledge this as a limitation of our study.

${ }^{23}$ For a similar application (albeit in a different context) of a panel probit model with random effects using firm (instead of time) dimension for modeling individual decisions, see Colombo and Delmastro (2004). It is worth noticing that a fixed effects model cannot be estimated since most of the independent variables are firm-specific and do not vary across founders.
} 
$30 \%$ of the shares of the start-up. As to firm-specific characteristics, most of the firms are located in the North and are active in Internet services rather than software. At the beginning of the bust period, start-ups were on average three years old. Specifically, considering the main (enlarged) sample, 20\% (21\%) of entrepreneurs founded their start-up in 1995, 30\% (31\%) in 1996, 25\% (20\%) in 1997, 7\% (9\%) in 1998, 18\% (19\%) in 1999-early 2000. Table 4 highlights the correlation matrix for the explanatory variables (we only report the one based on the main sample, the correlation matrix on the enlarged sample is fairly similar and available upon request from the authors).

[Table 2], [Table 3] and [Table 4]

\section{RESULTS}

\subsection{Main analysis}

Main results of the empirical analysis are reported in Table 5. Columns I and III show the results for the probit models with clustered errors, Column I considers work experience, while model's specification in Column III splits this variable into its generic and specific components. Columns II and IV show the same corresponding probit models but now estimated with random effects. Results are fairly consistent across models' specifications and estimation methodologies. Both the variables Education and Work experience show a positive and significant impact at conventional confidence levels on the likelihood of entrepreneurial leave. Overall, it is shown that higher levels of founder human capital are associated with a higher probability that a founder will decide to abandon the entrepreneurial venture. The positive effect of the work experience dimension on the founder's decision to leave the venture is found to apply to both its specific and generic component, with their difference being not statistically significant (chi2 (1) = 0.74 for Model in Column II; chi2 (1) $=0.42$ for Model in Column IV). The only human capital attribute which is found to mitigate exit dynamics of ICT entrepreneurs is the variable Managerial experience which shows a negative and significant coefficient in all 
regressions. This suggests that having gained a sufficient managerial experience in the pre-entry phase could raise confidence and capabilities of the entrepreneur of coping with the industryspecific crisis, making him, everything else being equal, more reluctant to abandon the newly created venture. But in order to gauge the overall magnitude of these effects and grasp their incidence on a founder's decision to exit, Figure 1 presents a computational exercise based on the estimates of the Probit model (with clustered errors) exposed in Column III of Table 5 (similar figures are obtained with the random effects specification).

[Figure 1]

A "benchmark" male individual characterized by a low level of human capital in terms of education (13 years) and work experience (three years of generic work experience and no specific work experience) and no past managerial episodes is the co-founder of a four-year-old Internet company established with two other individuals. This individual presents a probability to leave equal to $7.5 \%$. This percentage increases to $23.3 \%$ if his educational level is set at the $90^{\text {th }}$ percentile (18 years), everything else being equal as in the benchmark case. Setting the specific or the generic work experience at the $90^{\text {th }}$ percentile (16 and 19 years, respectively) increases his exit probability to $29.9 \%$ and $19.4 \%$, respectively. A high level of education and work experience altogether (i.e., corresponding variables set at their $90^{\text {th }}$ percentile) raises the probability of exit to a remarkable $77.6 \%$. This percentage drastically reduces but still remains noteworthy when compared to the benchmark case if, to this highly educated and professionally experienced individual, one also adds some managerial experience: in this case the probability of entrepreneurial leave is equal to $29.0 \%$. Elasticities and marginal effects of the human capital variables of interest, which highlight the same direction of impact and imply similar orders of magnitude with respect to the figures above exposed, are presented in the Appendix (Table A.1). In particular, a $1 \%$ increase in the education, sector specific and generic work experience 
variables increases the probability of exit by roughly $4.85 \%, 0.48 \%$ and $0.53 \%$, while having matured a managerial experience lowers the probability of exit by $16.1 \%$.

[Table 5]

\subsection{Robustness checks and additional evidence}

We perform several additional analyses in order to enlarge and deepen our main results.

First, we repeat the whole main analysis on the enlarged sample (including exited and/or single-founded firms), by performing a multinomial logit analysis (with clustered errors) that distinguishes the different exit routes for the founders: the individual (and unconstrained) decision to leave the start-up opposed to the exit due to closure or sale of the firm. The model specification is the one that distinguishes the different typologies of work experience. Results are exposed in Table 6. The impact of founders' human capital on the individual decision to leave the firms (columns I) mirrors the one highlighted in the main analysis. Equally interestingly, echoing the findings at firm-level already highlighted in Grilli (2011), results concerning the other exit modes still portray a (statistically weak) positive impact of founders' human capital on the closure and M\&A routes. Specifically, each single founder human capital variable is found to be more associated to exit via closure and/or M\&A rather than with the "staying" state, albeit no one of these coefficients is statistically significant at conventional levels.

[Table 6]

Secondly, our main analysis does not incorporate any treatment and consequent discussion on the temporal dynamics of a founder's exit. Considering the main (enlarged) sample, over the bust period 2000-2003, 25\% (41\%) of entrepreneurial exits occurred in the year 2000, 30\% (26\%) in the year 2001, 25\% (22\%) in the year 2002, 20\% (11\%) in the year 2003. To dig into this aspect and verify if the main results still hold when we take into consideration the yearly dynamics of founders' exits, we perform a specific survival duration analysis. Specifically, a 
first Weibull survival duration model was run on the main sample. Then, we also run a series of competing risks survival models on the enlarged sample (including exited firms and/or single founded), again distinguishing across the different exit modes. Results are illustrated in Table 7 , and they once more fully support the findings already highlighted. ${ }^{24}$ The Weibull survival duration model run on the main sample testifies again how highly endowed human capital founders were particularly prone to leave their firms. Findings from the competing risks analysis mirror those illustrated in Table 6, where founders' human capital variables impact positively also closure and M\&A, but with far less statistical significance.

\section{[Table 7]}

Third, our model's specification leaves aside an important founder's human capital characteristic which may clearly have an impact on the investigated dynamics: the founder's previous entrepreneurial experience. We have this information only on 178 founders. Table A2 in the Appendix reports the result of the probit (with clustered errors) specifications exposed in Table 5, while also inserting as an additional independent variable, a dummy Entrepreneurial experience capturing past entrepreneurial experience of the founder. Results highlight how this variable only loosely and statistically weakly impacts the investigated dynamics, while leaving the other findings substantially unaltered (with the only partial exception of the coefficient of Generic work experience which is now only close to significance).

Finally, we also explored the possible presence of non-linear relationships and super additive effects of and between the variables Education and Work experience (results available upon request from authors). After a de-meaning operation for alleviating multicollinearity concerns, the estimation of the basic specification with the linear and quadratic terms of these variables highlights positive and significant coefficients for linear terms as before in both

\footnotetext{
${ }^{24}$ Note that different choices as regards the survival distribution, like a lognormal or log-logistic distribution, lead to almost identical results to those presented here. We excluded from the survival model's specification the variable Age so to avoid any risk of a tautological correlation with the duration variable. However, it is worth noting that that its introduction leaves our findings again unchanged.
} 
typologies of probit models (with clustered errors and random effects), an always largely insignificant impact for the quadratic term of Education, and a negative impact for the quadratic term of Work experience, significant at $10 \%$ in the probit model with clustered errors and statistically insignificant in the probit model with random effects. Thus, the analysis points to important linear effects, documenting only a statistically weak inverted U-shaped relationship between the Work experience variable and founder exit. With the same logic, we also investigated the statistical significance of the coefficient for the interaction term Education $\times$ Work experience. The term turns out to be positive but again statistically insignificant without eroding the magnitude and statistical significance of the two original variables. The interpretation for this effect does not significantly change when the full range of covariate values is inspected computationally or graphically (as suggested by Ai and Norton, 2003; Hoetker, 2007). More specifically, the marginal effect of the interaction term Education $\times$ Work experience is positive but largely insignificant for most of the predicted probability values: the average Z-statistics is 1.14 . Figure 2 reports the Z-statistics for the whole picture and compare it with the Z-statistics 95\% bandwidth confidence interval. Most of the values of the interaction effect fall into the non-significance region.

[Figure 2]

\section{CONCLUDING REMARKS}

The aim of this study is to theoretically and empirically explore the possibility that during an industry-specific negative shock, more highly skilled and educated entrepreneurs could be more likely than low-profile ones to decide to leave the newly created entrepreneurial venture. Theoretically, we investigate the formal conditions under which this possibility becomes real. From an empirical point of view, we highlight that such phenomenon took place to some extent during a specific episode: in the severe industry recession that hit the ICT sector during the 2000-2003 period, high human capital profile entrepreneurs at Italian start-ups created in the 
sector during the boom period from 1995 to early 2000 were found on average to be more likely than low-skilled ones to quit the new entrepreneurial ventures they had just started.

This study extends a previous analysis conducted at firm-level on the complex and nuanced relationship between founders’ human capital and firm survival (Grilli, 2011), by focusing on the individual decision of an entrepreneur to stay on board or conversely leave the newly created start-up during a sector-specific downturn. In doing so, it reveals that industry crises may have subtle negative consequences for economic systems than what is generally understood. They could be less evident, but not for this, less dangerous. Indeed, researchers have generally evaluated the entrepreneurial exit from one sector and the subsequent entry into salaried workforce or self-employment into another sector by adopting a general equilibrium perspective. In this respect, the impact of entrepreneurial leave on the overall welfare might have an ambiguous sign. Following the line of reasoning inspired by the Schumpeterian “creative destruction” approach, exits from one sector might even generate additional opportunities in other sectors, resulting in a positive outcome for the economy as a whole (see for example Sobel and Dean, 2008). ${ }^{25}$ Instead, we stress the negative implications of an entrepreneurial exit phenomenon as the one we empirically documented in the previous sections. In particular, we argue that founder human capital is a primary asset for entrepreneurial ventures. This especially applies to start-ups created in knowledge-intensive and high-tech sectors (e.g. Cooper and Bruno, 1977; Feeser and Willard, 1990; Colombo and Grilli, 2005 and 2010; Kato et al., 2015), where founding entrepreneurs have the opportunity to imprint with their vision, actions and strategies the venture they create, strongly shaping all the subsequent development of the firm (on the "imprinting" effect of founder human capital on entrepreneurial ventures, see the seminal contributions of Boeker, 1988 and 1989; Baron et al. 1999; and more recent empirical analyses by Barringer et al., 2005; Roberts et al., 2011,;

\footnotetext{
${ }^{25}$ Some theoretical justifications in terms of overall efficiency of the firm-number overshooting in entry and the subsequent exit can be found for example in Jovanovic and MacDonald (1994) and Ericson and Pakes (1995).
} 
Schneider et al., 2007). On the other hand, human capital's endowment is an important factor in determining occupational choices (e.g. Paglin and Rufolo, 1990), and entrepreneurs clearly do not represent an exception to the rule (Davidsson and Honig, 2003). Our theoretical representation and empirical documentation has shown how the highest skilled ones could rationally act as modern Sisyphuses and be willing to "roll plans" again during an industry crisis. The founding imprinting effect discussed above is less likely to materialize the shorter is the time span between firm's creation and founder's leave. Accordingly, the leave of the most skilled and educated entrepreneurs from the start-ups they just helped to create is likely to exert an important sectorial loss of efficiency that goes beyond the mere absence of individual skills, but it is rooted on the reduced set of capabilities of the created entrepreneurial ventures. However this important burden risks not being the only one. In fact, embryonic business ideas are often highly idiosyncratic and difficult to transmit, as they are highly associated with particular individuals, and if these latter are not personally involved and strongly motivated to achieve such ideas, business ideas may simply not materialize. Consequently, sectorial negative shocks may produce the adverse selection phenomena highlighted here, not only for the entrepreneur human capital but also for the innovative and valuable business ideas associated with entrepreneurs. In this respect, the debate regarding social welfare losses associated with economic crises should also take into account these potential drastic reductions in the dynamic efficiency of the economic system. Interestingly, our argument has been shared in a somewhat different context by Darby and Zucker (2003). Referring to scientific discoveries and to the possibility that others than the discovering scientists may appropriate them, they claim: "When a major scientific breakthrough occurs and creates the opportunity for a corresponding incumbent-enhancing or entry-generating technological breakthrough, it may be very difficult for anyone other than the discovery scientists or their close working associates to reduce their discovery to technological practice. The ideas are far from codified and even the discovering 
scientists are not sure exactly what it is that are doing, which is crucial” (Darby and Zucker, 2003, p.11). In the same vein, as the potential of a scientific discovery is fully exploitable only by the scientists who realized it, innovative entrepreneurial ideas may get lost when a highly skilled founder leaves the firm (s)he contributed to create.

\section{REFERENCES}

Agarwal, R., and D. Audretsch (2001). "Does Entry Size Matter? The Impact of the Life Cycle and Technology on Firm Survival,” Journal of Industrial Economics 49, 21-43.

Ai, C., and E.C. Norton (2003). "Interaction Terms in Logit and Probit Models," Economics Letters 80, 123-129.

Allen, I.E., and N.S. Langowitz (2011). "Understanding the Gender Gap in Entrepreneurship: A Multicountry Examination" in M. Minniti, The Dynamics of Entrepreneurship, Oxford University Press.

Amit, R., E. Muller, and I. Cockburn (1995). “Opportunity Costs and Entrepreneurial Activity,” Journal of Business Venturing 10, 95-106.

Arora, A., and A. Nandkumar (2011). "Cash-out or Flameout! Opportunity Cost and Entrepreneurial Strategy: Theory, and Evidence from the Information Security Industry,” Management Science 57, 1844-1860.

Arum, R., and W. Muller (2004). The Re-Emergence of Self-Employment: A Comparative Study of SelfEmployment Dynamics and Social Inequality. Princeton, NJ: Princeton University Press.

Assinform (2006). Rapporto Assinform sull'Informatica e le Telecomunicazioni e i Contenuti Multimediali. AITech-Assinform, Milano.

Baron, J.N., Hannan, M.T., and M.D. Burton (1999). "Building the Iron Cage: Determinants of Managerial Intensity in the Early Years of Organizations," American Sociological Review 64, 527-547.

Barringer, B.R., Jones, F.F., and D.O. Neubaum (2005). "A Quantitative Content Analysis of the Characteristics of Rapid-Growth Firms and their Founders," Journal of Business Venturing 20, 663-687.

Bates, T. (1989). "Small Business Viability in the Urban Ghetto," Journal of Regional Science 29, 625-643.

Bates, T. (1995). "Self-Employment Entry across Industry-Groups,” Journal of Business Venturing 10, 143-156.

Becker, G.S. (1975). Human Capital. National Bureau of Economic Research, New York.

Boeker, W. (1988). "Organizational Origins: Entrepreneurial and Environmental Imprinting at the Time of Founding” in G.R. Carroll, Ecological Models of Organizations, Ballinger, Cambridge MA.

Boeker, W. (1989). "The Development and Institutionalization of Subunit Power in Organizations," Administrative Science Quarterly 34, 388-410.

Bottazzi, L., Da Rin, M., and T. Hellmann (2008). "Who are the Active Investors? Evidence from Venture Capital,” Journal of Financial Economics 89, 488-512.

Bresnahan, T.F., and M. Trajtenberg (1995). “General Purpose Technologies ‘Engines of Growth’?,” Journal of Econometrics 65, 83-108.

Bruce, D. (2002). “Taxes and Entrepreneurial Endurance: Evidence from the Self-Employed,” National Tax Journal 55, 5-24.

Burke, A.E., M.A. Nolan, and F.R. FitzRoy (2008). "What Makes a Die-Hard Entrepreneur? Beyond the 'Employee or Entrepreneur' Dichotomy,” Small Business Economics 31, 93-115.

Coad, A., J. Frankish, R.G. Roberts, and D.J. Storey (2013). "Growth Paths and Survival Chances: an Application of Gambler's Ruin Theory,” Journal of Business Venturing 28, 615-632. 
Colombo, M.G., and M. Delmastro (2004). "Delegation of Authority in Business Organizations: an Empirical Test,” Journal of Industrial Economics 52, 53-80.

Colombo, M.G., M. Delmastro, and L. Grilli (2004). “Entrepreneurs’ Human Capital and the Start-up Size of New Technology-based Firms,” International Journal of Industrial Organization 22, 1183-1211.

Colombo, M.G., and L. Grilli (2005). “Founders’ Human Capital and the Growth of New Technology-based Firms: a Competence Based View,” Research Policy 34, 795-816.

Colombo, M.G., and L. Grilli (2010). “On Growth Drivers of High-tech Start-ups: Exploring the Role of Founders’ Human Capital and Venture Capital,” Journal of Business Venturing 25, 610-626.

Colombo, M.G., and L. Grilli (2013). “The Creation of a Middle-management Level by Entrepreneurial Ventures: Testing Economic Theories of Organizational Design,” Journal of Economics \& Management Strategy 22, 390-422.

Cooper, A.C. and A.V. Bruno (1977). “Success among High-technology Firms,” Business Horizons 20, $16-22$.

Cressy, R. (1996). “Are Business Start-ups Debt Rationed?,” Economic Journal 106, 1253-1270.

Criaco, G., T. Minola, P. Migliorini, and C. Serarols-Tarrés (2014). “To have and have not: founders’ human capital and university start-up survival”, Journal of Technology Transfer 39, 567-593.

Cumming, D. (2006). “Adverse Selection and Capital Structure: Evidence from Venture Capital,” Entrepreneurship Theory and Practice 30, 155-184.

Dahl, M.S., and T. Reichstein (2007). "Are You Experienced? Prior Experience and the Survival of New Organizations,” Industry and Innovation 14, 497-511.

Darby, M.R., and L.G. Zucker (2003). “Growing by Leaps and Inches: Creative Destruction, Real Cost Reduction, and Inching Up,” Economic Inquiry 41, 1-19.

Day, R.H. (1971). “Rational Choice and Economic Behavior,” Theory and Decision 1, 229-251.

Davidsson, P., and B. Honig (2003). “The Role of Social and Human Capital among Nascent Entrepreneurs," Journal of Business Venturing 18, 301-331.

Delmar, F., and S. Shane (2006). "Does Experience Matter? The Effect of Founding Team Experience on the Survival and Sales of Newly Founded Ventures,” Strategic Organization 4, 215-247.

DeTienne, D.R., D.A. Shepherd, and J.O. De Castro (2008). “The Fallacy of 'Only the Strong Survive’: The Effects of Extrinsic Motivation on the Persistence Decisions for Under-performing Firms,” Journal of Business Venturing 23, 528-546.

DeTienne, D.R, and M.S. Cardon (2012). “Impact of Founder Experience on Exit Intentions,” Small Business Economics 38, 351-374.

EITO (2004). European Information Technology Observatory 2004. European Information Technology Observatory, Frankfurt.

Ericson, R., and A. Pakes (1995). “Markov-Perfect Industry Dynamics: a Framework for Empirical Work,” Review of Economic Studies 62, 53-82.

Evans, D., and B. Jovanovic (1989). “An Estimated Model of Entrepreneurial Choice under Liquidity Constraints,” Journal of Political Economy 97, 808-827.

Evans, D., and L. Leighton (1989). “Some Empirical Aspects of Entrepreneurship,” American Economic Review 79, 519-535.

Feeser, H.R. and G.E. Willard (1990). "Founding Strategy and Performance: a Comparison of High and Low Growth High Tech Firms,” Strategic Management Journal 11, 87-98.

Folta, T.B., F. Delmar, and K. Wennberg (2010). “Hybrid Entrepreneurship,” Management Science 56, $253-269$.

Fransman, M. (2004). “The Telecoms Boom and Bust 1996-2003 and the Role of Financial Markets,” Journal of Evolutionary Economics 14, 369-406.

Gimeno, J., T.B. Folta, A. Cooper, and C. Woo (1997). "Survival of the Fittest? Entrepreneurial Human Capital and the Persistence of Underperforming Firms,” Administrative Science Quarterly 42, 750-783.

Gimmon, E., and J. Levie (2010). “Founders’ Human Capital, External Investment, and the Survival of New HighTechnology Ventures,” Research Policy 39, 1214-1226. 
Grilli, L. (2011). "When the Going Gets Tough, Do the Tough Get Going? The Pre-Entry Work Experience of Founders and High-Tech Start-Up Survival during an Industry Crisis,” International Small Business Journal 29, 626-647.

Headd, B. (2003). “Redefining Business Success: Distinguishing between Closure and Failure,” Small Business Economics 21, 51-61.

Hellmann, T., and M. Puri (2002). "Venture Capital and the Professionalization of Start-up Firms: Empirical Evidence,” Journal of Finance 57, 169-197.

Hoetker, G. (2007). “The Use of Logit and Probit Models in Strategic Management Research: Critical Issues,” Strategic Management Journal 28, 331-343.

Holland, D.V., and R.P. Garret (2015). “Entrepreneur Start-up versus Persistence Decisions: A Critical Evaluation of Expectancy and Value,” International Small Business Journal 33, 194-215.

Holmes, T.J., and J.A. Schmitz (1990). “A Theory of Entrepreneurship and its Application to the Study of Business Transfers,” Journal of Political Economy 98, 265-294.

Holmes, T.J., and J.A. Schmitz (1995). “On the Turnover of Business Firms and Business Managers,” Journal of Political Economy 103, 1005-1038.

Hundsdoerfer, J., and C. Sichtmann (2009). "The importance of taxes in entrepreneurial decision: an analysis of practicing physicians’ behavior,” Review of Managerial Science 3, 19-40.

Jovanovic, B., and G. MacDonald (1994). “The Life-Cycle of a Competitive Industry,” Journal of Political Economy 102, 322-347.

Kam, J. (2006). “No Pain no Gain: Rethinking the Telecom Crash,” Technology Analysis \& Strategic Management $18,497-514$.

Kato, M., H. Okamuro, and Y. Honjo (2015). “Does Founders’ Human Capital Matter for Innovation? Evidence from Japanese Start-ups,” Journal of Small Business Management 53, 114-128.

Li, H., L. Meng, and J. Zhang (2006). “Why do Entrepreneurs Enter Politics? Evidence from China,” Economic Inquiry 44, 559-578.

Mata, J., P. Portugal, and P. Guimarães (1995). “The Survival of New Plants: Start-up Conditions and Post-Entry Evolution,” International Journal of Industrial Organization 13, 459-481.

McGrath, R. (1999). “Falling Forward: Real Options Reasoning and Entrepreneurial Failure,” Academy of Management Review 24, 13-30.

Paglini, M., and A. Rufolo (1990). "Heterogenous Human Capital, Occupational Choice, and Male-Female Earnings Differences,” Journal of Labor Economics 8, 123-144.

Parker, S.C. (2009). The Economics of Entrepreneurship. Cambridge University Press, Cambridge UK.

Roberts, P.W., Klepper, S., and S. Hayward (2011). "Founder Backgrounds and the Evolution of Firm Size,” Industrial and Corporate Change 20, 1515-1538.

Santarelli, E., and M. Vivarelli (2007). "Entrepreneurship and the Process of Firms’ Entry, Survival and Growth,” Industrial and Corporate Change 16, 455-488.

Shane, S., and T. Stuart (2002). “Organizational Endowments and the Performance of University Start-ups,” Management Science 48, 154-170.

Schäfer, D., Werwatz, A., and V. Zimmermann (2004). “The Determinants of Debt and (Private) Equity Financing: the Case of Young, Innovative SMEs from Germany,” Industry and Innovation 11, 225-248.

Schäfer, D., and O. Talavera (2009). “Small Business Survival and Inheritance: Evidence from Germany,” Small Business Economics 32, 95-109.

Schiller, B.R., and P.E. Crewson (1997). “Entrepreneurial Entry: a Longitudinal Inquiry,” Economic Inquiry 35, 523-531.

Schneider, J.K., M. Dowling, and S. Raghuram (2007). "Empowerment as a success factor in start-up companies,” Review of Managerial Science 1, 167-184.

Sobel, R.S., and A.M. Dean (2008). "Has Wal-Mart Buried Mom and Pop?: the Impact of Wal-Mart on SelfEmployment and Small Establishments in the United States,” Economic Inquiry 46, 676-695. 
Stam, E., R. Thurik, and P. van der Zwan (2010). “Entrepreneurial Exit in Real and Imagined Markets,” Industrial and Corporate Change 19, 1109-1139.

Storey, D.J., and P. Wynarczyk (1996). “The Survival and Non-survival of Micro Firms in the UK,” Review of Industrial Organization 11, 211-229.

Taylor, M.P. (1999). "Survival of the Fittest? An Analysis of Self-employment Duration in Britain,” Economic Journal 109, C140-C155.

Thompson, P. (2005). "Selection and Firm Survival: Evidence from the Shipbuilding Industry, 1825-1914," Review of Economics and Statistics 87, 26-36.

Unger, J.M., A. Rauch, M. Frese and N. Rosenbusch (2011). "Human Capital and Entrepreneurial Success: a Metaanalytical Review,” Journal of Business Venturing 26, 341-358.

Van Praag, C.M. (2003). “Business Survival and Success of Young Small Business Owners,” Small Business Economics 21, 1-17.

Wennberg, K. (2012). “Entrepreneurial Exit,” in L.P. Dana, World Encyklopedia of Entrepreneurship, Celtenham: Edward Elgar.

Wennberg, K., J. Wiklund, D.R. DeTienne, and M.S. Cardon (2010). "Reconceptualizing Entrepreneurial Exit: Divergent Exit Routes and their Drivers,” Journal of Business Venturing 25, 361-375.

\section{Tables \& figures}

Table 1 - Model's predictions when condition C2 holds (does not hold)

\section{Level of human capital}

\begin{tabular}{c|c|c}
\hline \hline & Low & High \\
\hline Boom & high (low) likelihood of entry & low (high) likelihood of entry \\
\hline
\end{tabular}




\begin{tabular}{ll|l|l}
\hline $\begin{array}{l}\text { Industry } \\
\text { conditions }\end{array}$ & Bust & low (high) likelihood of leave & high (low) likelihood of leave \\
\hline \hline
\end{tabular}

Table 2 - Definition of explanatory variables

\begin{tabular}{ll}
\hline \hline $\begin{array}{l}\text { Explanatory } \\
\text { variables }\end{array}$ & \\
\hline & Founder characteristic \\
\hline Education & Number of years of education of the founder \\
$\begin{array}{l}\text { Work } \\
\text { experience }\end{array}$ & Number of years of work experience of the founder
\end{tabular}


Specific work Number of years of work experience of the founder gained in the same sector of experience the start-up before firm's foundation

Generic work Number of years of work experience of the founder gained in another sector of experience the start-up before firm's foundation

Managerial Value of 1 if the founder had a previous high managerial position in another experience company

Founder-specific controls

Share founder Percentage of shareholdings possessed by the founder at foundation

Female $\quad$ Value of 1 if the founder is female

Firm -specific controls

\begin{tabular}{ll}
\hline Founders & Size of the founding team (number of entrepreneurs) \\
Size & Logarithm of number of employees at the end of 1999
\end{tabular}

Bank debt Value of 1 for firms which have obtained a bank debt at firm’s foundation

VC Value of 1 for firms that received a venture capital investment from foundation till the end of 1999

Age $\quad$ Number of years from 2000 to firm’s foundation

Other controls

Internet Value of 1 for firms operating in Internet services (e-commerce, ISP, web-related services).

Infrastructure Value of the index measuring regional infrastructures (mean value among Italian regions=100; source: Centro Studi Confindustria)

South Macro-regional dummy taking value of 1 if the start-up is located in the South of Italy

Centre Macro-regional dummy taking value of 1 if the start-up is located in the Centre of Italy

North-west Macro-regional dummy taking value of 1 if the start-up is located in the NorthWest of Italy 
Table 3 - Descriptive statistics

\begin{tabular}{|c|c|c|c|c|c|c|c|c|}
\hline \multirow{4}{*}{ Columns } & \multicolumn{4}{|c|}{ Main sample } & \multicolumn{4}{|c|}{ Enlarged sample } \\
\hline & $I$ & II & III & $I V$ & & & & \\
\hline & \multicolumn{2}{|c|}{ All founders } & \multirow{2}{*}{$\begin{array}{c}\text { Stayers } \\
\text { Mean }\end{array}$} & \multirow{2}{*}{$\begin{array}{c}\text { Leavers } \\
\text { Mean }\end{array}$} & \multicolumn{2}{|c|}{ All founders } & \multirow{2}{*}{$\begin{array}{c}\text { Stayers } \\
\text { Mean }\end{array}$} & \multirow{2}{*}{$\begin{array}{c}\text { Leavers } \\
\text { Mean }\end{array}$} \\
\hline & Mean & S.D. & & & Mean & S.D. & & \\
\hline Education & 15.075 & 2.851 & 14.945 & 16.250 & 15.008 & 2.877 & 14.941 & 15.163 \\
\hline Work experience & 10.189 & 8.333 & 10.089 & 11.100 & 10.669 & 8.481 & 10.161 & 11.850 \\
\hline Specific work experience & 3.706 & 7.192 & 3.757 & 3.250 & 4.177 & 7.438 & 3.952 & 4.700 \\
\hline Generic work experience & 6.483 & 8.070 & 6.331 & 7.850 & 6.492 & 8.387 & 6.210 & 7.150 \\
\hline Managerial experience & 0.119 & 0.325 & 0.127 & 0.050 & 0.135 & 0.343 & 0.124 & 0.163 \\
\hline Share founder & 31.209 & 16.470 & 31.982 & 24.210 & 33.912 & 20.084 & 33.246 & 35.460 \\
\hline Female & 0.149 & 0.357 & 0.155 & 0.100 & 0.147 & 0.354 & 0.151 & 0.138 \\
\hline Founders & 3.637 & 1.460 & 3.591 & 4.050 & 3.485 & 1.488 & 3.522 & 3.400 \\
\hline Size & 1.218 & 0.876 & 1.192 & 1.447 & 1.282 & 0.951 & 1.196 & 1.483 \\
\hline Bank debt & 0.164 & 0.371 & 0.171 & 0.100 & 0.135 & 0.343 & 0.172 & 0.050 \\
\hline$V C$ & 0.109 & 0.313 & 0.105 & 0.150 & 0.105 & 0.307 & 0.102 & 0.113 \\
\hline Age & 3.184 & 1.530 & 3.303 & 2.100 & 3.180 & 1.539 & 3.306 & 2.888 \\
\hline Internet & 0.607 & 0.490 & 0.597 & 0.700 & 0.639 & 0.481 & 0.586 & 0.763 \\
\hline Infrastructure & 107.073 & 33.232 & 106.300 & 114.065 & 109.538 & 31.486 & 106.263 & 117.153 \\
\hline South & 0.279 & 0.449 & 0.276 & 0.300 & 0.241 & 0.428 & 0.274 & 0.163 \\
\hline Centre & 0.119 & 0.325 & 0.122 & 0.100 & 0.128 & 0.335 & 0.118 & 0.150 \\
\hline North-West & 0.413 & 0.494 & 0.425 & 0.300 & 0.462 & 0.500 & 0.435 & 0.525 \\
\hline
\end{tabular}


Table 4-Correlation matrix of the explanatory variables of the econometric model

\begin{tabular}{|c|c|c|c|c|c|c|c|c|c|c|c|c|c|c|c|c|}
\hline Variable & 1 & 2 & 3 & 4 & 5 & 6 & 7 & 8 & 9 & 10 & 11 & 12 & 13 & 14 & 15 & 16 \\
\hline 1. Education & 1 & & & & & & & & & & & & & & & \\
\hline 2. Work experience & -0.3253 & 1 & & & & & & & & & & & & & & \\
\hline 3. Specific work experience & -0.2564 & 0.4676 & 1 & & & & & & & & & & & & & \\
\hline 4. Generic work experience & -0.1074 & 0.6160 & -0.4083 & 1 & & & & & & & & & & & & \\
\hline 5. Managerial experience & -0.0097 & 0.2537 & 0.2995 & -0.0049 & 1 & & & & & & & & & & & \\
\hline 6. Share founder & 0.0493 & 0.0768 & 0.0454 & 0.0388 & 0.0132 & 1 & & & & & & & & & & \\
\hline 7. Female & -0.0355 & -0.0179 & -0.0704 & 0.0443 & -0.0681 & 0.0336 & 1 & & & & & & & & & \\
\hline 8. Founders & -0.0787 & 0.1162 & -0.1088 & 0.2169 & -0.0557 & -0.5794 & 0.0853 & 1 & & & & & & & & \\
\hline 9. Size & 0.0780 & 0.0341 & 0.0188 & 0.0185 & 0.0640 & -0.1271 & 0.0725 & 0.1563 & 1 & & & & & & & \\
\hline 10. Bank debt & -0.0589 & 0.0901 & 0.1885 & -0.0750 & 0.0025 & 0.2300 & 0.0405 & -0.2767 & -0.0376 & 1 & & & & & & \\
\hline 11. $V C$ & 0.0804 & 0.0112 & -0.1012 & 0.1017 & -0.0308 & 0.0284 & -0.0574 & -0.0001 & 0.2326 & -0.1124 & 1 & & & & & \\
\hline 12. Age & -0.0777 & -0.0114 & -0.0310 & 0.0159 & -0.2756 & -0.0060 & 0.0318 & 0.1666 & 0.0853 & 0.0169 & -0.0840 & 1 & & & & \\
\hline 13. Internet & -0.0863 & -0.1790 & -0.0698 & -0.1226 & 0.0136 & -0.0134 & -0.0917 & -0.2216 & 0.0205 & 0.0542 & 0.0211 & -0.2433 & 1 & & & \\
\hline 14. Infrastructure & 0.0820 & -0.0217 & -0.1853 & 0.1427 & 0.0545 & 0.0700 & -0.0103 & 0.0419 & 0.2570 & -0.0647 & 0.0466 & -0.1542 & -0.1685 & 1 & & \\
\hline 15. South & -0.0670 & -0.0101 & 0.1708 & -0.1627 & -0.0577 & -0.0826 & 0.1134 & 0.0102 & -0.0989 & 0.1140 & -0.0401 & 0.1286 & 0.1593 & -0.8256 & 1 & \\
\hline 16. Centre & 0.1522 & -0.1210 & -0.1860 & 0.0408 & -0.0883 & 0.0166 & -0.0251 & -0.0557 & -0.0016 & -0.0804 & 0.2641 & 0.1466 & -0.0806 & 0.2073 & -0.2288 & 1 \\
\hline 17. North-West & -0.0007 & 0.1365 & -0.0192 & 0.1581 & 0.0340 & 0.1411 & -0.0677 & -0.0476 & -0.0977 & 0.0102 & -0.0998 & -0.2336 & -0.0699 & 0.4088 & -0.5212 & -0.3088 \\
\hline
\end{tabular}

Legend. Number of observations is 201. 
Table 5 - Founder human capital and probability of exit

\begin{tabular}{|c|c|c|c|c|c|}
\hline & Model & $\begin{array}{l}\text { Probit } \\
\text { (clustered } \\
\text { errors) } \\
1\end{array}$ & $\begin{array}{l}\text { Random effect } \\
\text { probit model }\end{array}$ & $\begin{array}{c}\text { Probit } \\
\text { (clustered } \\
\text { errors) }\end{array}$ & $\begin{array}{c}\text { Random effect } \\
\text { probit model } \\
\text { IV }\end{array}$ \\
\hline & Dependent variable & Leave & Leave & Leave & Leave \\
\hline$a_{1}$ & Constant & $-4.300(1.588)^{* * *}$ & $-4.833(2.323)^{* *}$ & $-4.670(1.681)^{* * *}$ & $-5.154(2.402)^{* *}$ \\
\hline$a_{2}$ & Education & $0.129(0.050)^{* * *}$ & $0.139(0.069)^{* *}$ & $0.142(0.051)^{* * *}$ & $0.152(0.073)^{* *}$ \\
\hline$a_{3}$ & Work experience & $0.042(0.015)^{* * *}$ & $0.044(0.026)^{*}$ & - & - \\
\hline$a_{4}$ & Specific work experience & - & - & $0.057(0.019)^{* * *}$ & $0.059(0.034)^{*}$ \\
\hline$a_{5}$ & Generic work experience & - & - & $0.036(0.020)^{*}$ & $0.038(0.027)$ \\
\hline$a_{6}$ & Managerial experience & $-1.199(0.488)^{* *}$ & $-1.302(0.666)^{* *}$ & $-1.310(0.440)^{* * *}$ & $-1.432(0.715)^{* *}$ \\
\hline$a_{7}$ & Share founder & $-0.019(0.010)^{*}$ & $-0.021(0.016)$ & $-0.021(0.011)^{* *}$ & $-0.023(0.016)$ \\
\hline$a_{8}$ & Female & $-0.305(0.367)$ & $-0.359(0.520)$ & $0.260(0.367)$ & $-0.313(0.523)$ \\
\hline$a_{9}$ & Founders & $0.161(0.168)$ & $0.159(0.158)$ & $0.183(0.175)$ & $0.178(0.161)$ \\
\hline$a_{10}$ & Size & $0.114(0.195)$ & $0.156(0.244)$ & $0.091(0.198)$ & $0.130(0.244)$ \\
\hline$a_{11}$ & Bank debt & $-0.245(0.487)$ & $-0.242(0.631)$ & $-0.284(0.461)$ & $-0.283(0.636)$ \\
\hline$a_{12}$ & $V C$ & $-0.330(0.458)$ & $-0.311(0.628)$ & $-0.301(0.462)$ & $-0.283(0.627)$ \\
\hline$a_{13}$ & Age & $-0.440(0.135)^{* * *}$ & $-0.475(0.164)^{* * *}$ & $-0.449(0.140)^{* * *}$ & -0.480 \\
\hline$a_{14}$ & Internet & $0.222(0.396)$ & $0.185(0.490)$ & $0.254(0.397)$ & $0.217(0.489)$ \\
\hline$a_{15}$ & Infrastructure & $0.014(0.008)^{*}$ & $0.017(0.011)$ & $0.015(0.008)^{*}$ & $0.018(0.011)$ \\
\hline$a_{16}$ & South & $1.017(0.780)$ & $1.257(1.032)$ & $1.042(0.791)$ & $1.258(1.018)$ \\
\hline$a_{17}$ & Centre & $-0.034(0.482)$ & $-0.013(0.739)$ & $0.015(0.508)$ & $0.023(0.735)$ \\
\hline$a_{18}$ & North-West & $-0.799(0.445)^{*}$ & $-0.811(0.592)$ & $-0.774(0.450)^{*}$ & $-0.794(0.586)$ \\
\hline & $N^{\circ}$ founders & 201 & 201 & 201 & 201 \\
\hline & $N^{\circ}$ of firms & 79 & 79 & 79 & 79 \\
\hline & Log-likelihood function & -45.925 & -45.515 & -45.652 & -45.304 \\
\hline & pseudo $R^{2}$ & 0.29 & - & 0.30 & - \\
\hline
\end{tabular}

Legend. Significance levels: * >10\%; ** >5\%; *** >1\%. 
Table 6 - Founder human capital and probability of exit in the enlarged sample: Multinomial logit model distinguishing founder's exit route.

\begin{tabular}{|c|c|c|c|c|}
\hline & \multirow{3}{*}{$\begin{array}{l}\text { Model } \\
\text { Columns } \\
\text { Dependent variable }\end{array}$} & \multicolumn{3}{|c|}{ Multinomial logit model (clustered errors) } \\
\hline & & $I$ & II & III \\
\hline & & Individual Leave & Closure & $M \& A$ \\
\hline$a_{1}$ & Constant & $-9.165(3.096)^{* * *}$ & $-0.208(3.489)$ & $-29.026(5.620)^{* * *}$ \\
\hline$a_{2}$ & Education & $0.257(0.091)^{* * *}$ & $0.007(0.075)$ & $0.005(0.086)$ \\
\hline$a_{3}$ & Specific work experience & $0.103(0.033)^{* * *}$ & $0.032(0.039)$ & $0.036(0.054)$ \\
\hline$a_{4}$ & Generic work experience & $0.070(0.036)^{* *}$ & $0.033(0.020)$ & $0.026(0.046)$ \\
\hline$a_{5}$ & Managerial experience & $-2.284(0.977)^{* *}$ & $0.357(0.846)$ & $0.760(0.598)$ \\
\hline$a_{6}$ & Share founder & $-0.036(0.022)$ & $0.018(0.013)$ & $0.019(0.012)$ \\
\hline$a_{7}$ & Female & $-0.520(0.795)$ & $0.715(0.644)$ & $-0.136(0.608)$ \\
\hline$a_{8}$ & Founders & $0.408(0.400)$ & $-0.303(0.232)$ & $0.004(0.313)$ \\
\hline$a_{9}$ & Size & $0.321(0.397)$ & $0.104(0.436)$ & $0.798(0.418)^{*}$ \\
\hline$a_{10}$ & Bank debt & $-0.364(0.982)$ & $-0.893(1.178)$ & $-16.891(0.683)^{* * *}$ \\
\hline$a_{11}$ & $V C$ & $-0.399(0.830)$ & $-16.248(0.795)^{* * *}$ & $-0.704(0.907)$ \\
\hline$a_{12}$ & Age & $-0.880(0.301)^{* * *}$ & $-0.115(0.386)$ & $0.069(0.215)$ \\
\hline$a_{13}$ & Internet & $0.635(0.729)$ & $0.536(0.857)$ & $1.391(1.025)$ \\
\hline$a_{14}$ & Infrastructure & $0.029(0.017)^{*}$ & $-0.014(0.018)$ & $0.051(0.031)^{*}$ \\
\hline$a_{15}$ & South & 1.977 (1.623) & $-1.884(1.544)$ & $20.305(3.442)^{* * *}$ \\
\hline$a_{16}$ & Centre & $0.033(0.917)$ & $0.097(1.183)$ & $18.322(1.640)^{* * *}$ \\
\hline$a_{17}$ & North-West & $-1.257(0.812)$ & $-0.736(1.048)$ & $18.032(1.498)^{* * *}$ \\
\hline & $N^{\circ}$ founders & & 266 & \\
\hline & $N^{\circ}$ of firms & & 111 & \\
\hline & Log-likelihood function & & -179.773 & \\
\hline & pseudo $R^{2}$ & & 0.27 & \\
\hline
\end{tabular}

Legend. Significance levels: * >10\%; ** >5\%; *** >1\%. Stayers is the benchmark category. 
Table 7 - Founder human capital and probability of exit: the survival and competing risks analyses

\begin{tabular}{|c|c|c|c|c|c|}
\hline & \multirow{2}{*}{$\begin{array}{l}\text { Model } \\
\text { Columns }\end{array}$} & \multirow{2}{*}{$\begin{array}{c}\text { Weibull Survival } \\
\text { model } \\
1\end{array}$} & \multicolumn{3}{|c|}{ Competing risks Weibull Survival models } \\
\hline & & & II & III & $I V$ \\
\hline & Dependent variable & Individual Leave & Individual Leave & Closure & $M \& A$ \\
\hline$a_{1}$ & Constant & $-9.836(2.261)^{* * *}$ & $-6.950(1.640)^{* * *}$ & $-1.550(2.093)$ & $-14.049(2.801)^{* * *}$ \\
\hline$a_{2}$ & Education & $0.193(0.074)^{* * *}$ & $0.125(0.055)^{* *}$ & $-0.008(0.076)$ & $0.016(0.026)$ \\
\hline$a_{3}$ & Specific work experience & $0.076(0.027)^{* * *}$ & $0.055(0.021)^{* * *}$ & $0.018(0.029)$ & $0.015(0.015)$ \\
\hline$a_{4}$ & Generic work experience & $0.060(0.021)^{* * *}$ & $0.050(0.014)^{* * *}$ & $0.010(0.021)$ & $0.009(0.015)$ \\
\hline$a_{5}$ & Managerial experience & $-0.962(0.830)$ & $-0.749(0.658)$ & $0.446(0.586)$ & $0.489(0.235)^{* *}$ \\
\hline$a_{6}$ & Share founder & $-0.037(0.016)^{* *}$ & $-0.035(0.010)^{* * *}$ & $0.007(0.014)$ & $0.006(0.006)$ \\
\hline$a_{7}$ & Female & $-0.537(0.614)$ & $-0.463(0.407)$ & $0.915(0.530)^{*}$ & $-0.004(0.272)$ \\
\hline$a_{8}$ & Founders & $-0.004(0.216)$ & $-0.029(0.195)$ & $-0.158(0.188)$ & $0.006(0.109)$ \\
\hline$a_{9}$ & Size & $-0.141(0.262)$ & $-0.190(0.242)$ & $-0.252(0.295)$ & $0.188(0.113)^{*}$ \\
\hline$a_{10}$ & Bank debt & $-0.195(0.690)$ & $-0.037(0.525)$ & $-11.926(3.680)^{* * *}$ & $-7.097(1.034)^{* * *}$ \\
\hline$a_{11}$ & $V C$ & $0.293(0.825)$ & $0.485(0.660)$ & $-11.591(3.486)^{* * *}$ & $-0.296(0.305)$ \\
\hline$a_{12}$ & Internet & $1.062(0.698)$ & $0.705(0.568)$ & $0.305(0.630)$ & $0.625(0.394)$ \\
\hline$a_{13}$ & Infrastructure & $0.026(0.013)^{* *}$ & $0.020(0.010)^{* *}$ & $-0.011(0.012)$ & $0.022(0.013)^{*}$ \\
\hline$a_{14}$ & South & $0.987(1.379)$ & $0.596(1.078)$ & $-1.412(1.347)$ & $8.496(2.025)^{* * *}$ \\
\hline$a_{15}$ & Centre & $-0.816(0.974)$ & $-0.946(0.766)$ & $-0.033(1.013)$ & $7.508(1.234)^{* * *}$ \\
\hline$a_{16}$ & North-West & $-0.544(0.554)$ & $-0.758(0.550)$ & $-0.648(1.020)$ & $7.507(1.217)^{* * *}$ \\
\hline & $N^{\circ}$ founders & 201 & 261 & 261 & 261 \\
\hline & $N^{\circ}$ of firms & 79 & 108 & 108 & 108 \\
\hline & Log-likelihood function & -70.440 & -64.899 & -62.254 & -76.981 \\
\hline & Wald $\chi^{2}(15)$ & 79.79 & 69.02 & 139.02 & 105.62 \\
\hline
\end{tabular}

Legend. Significance levels: * >10\%; ** >5\%; ***>1\%. Accelerated failure-time models. To increase readability and comparability with results of Table 5, the sign of coefficients has been reversed, so now a positive coefficient means an increase in the hazard of exit. Note that number of observations in the competing risk analysis is 261 and not 266 because for 5 entrepreneurs we were unable to ascertain with a sufficient degree of confidence the precise year of exit. 


\section{Figure 1 - Probability of entrepreneurial leave for different levels and combinations of founder human capital}

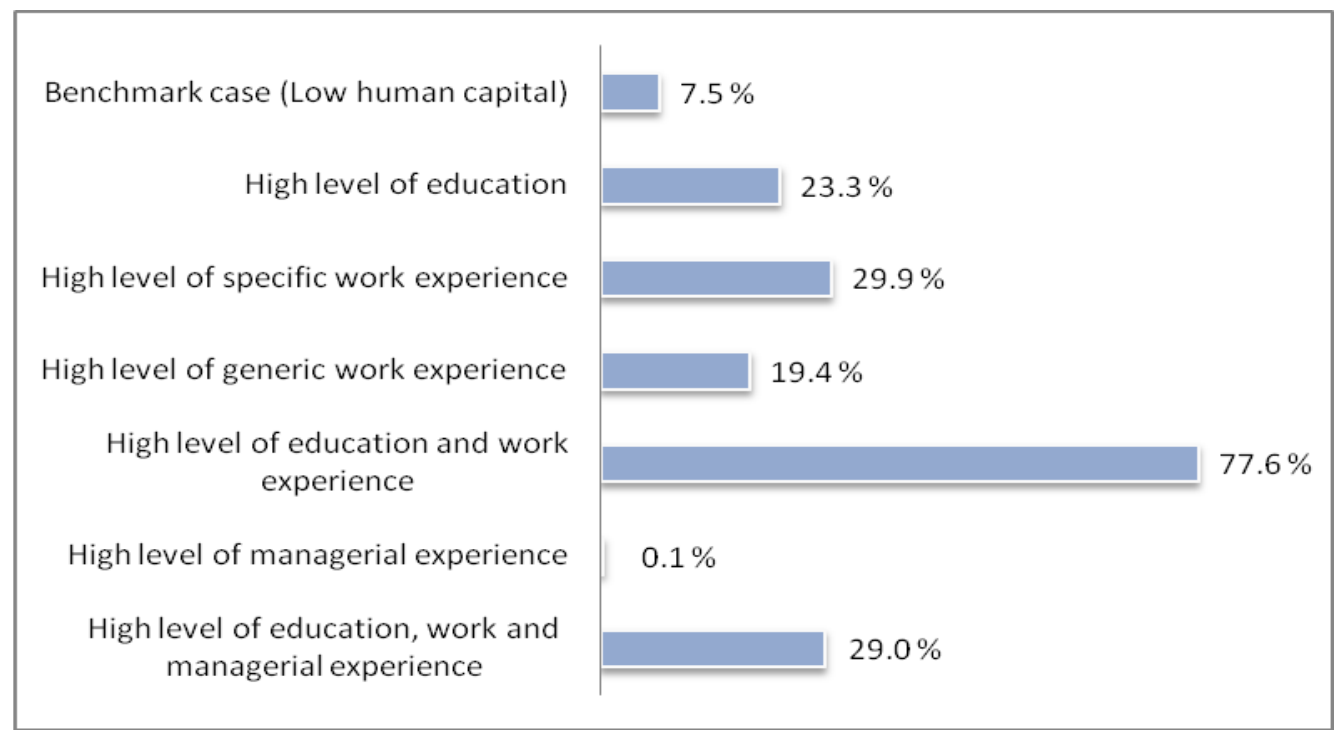

Legend. Computational exercise based on the estimates of the Probit model with clustered errors reported in Table 5, Column III. The benchmark individual is set at median value of the independent variables and represent a entrepreneur co-founder with other two individuals of a four-year-old Internet company, characterized by a low human capital level, i.e. 13 years of education, 3 years of generic work experience and no specific work experience. All the other exposed cases are obtained from the benchmark case, setting the variable(s) of interest at the $90^{\text {th }}$ percentile (high level education at 18 years, specific work experience at 16 years, generic work experience at 19 years, managerial experience equal to 1 ).

Figure 2 - Interaction effect: Education $\times$ Work experience

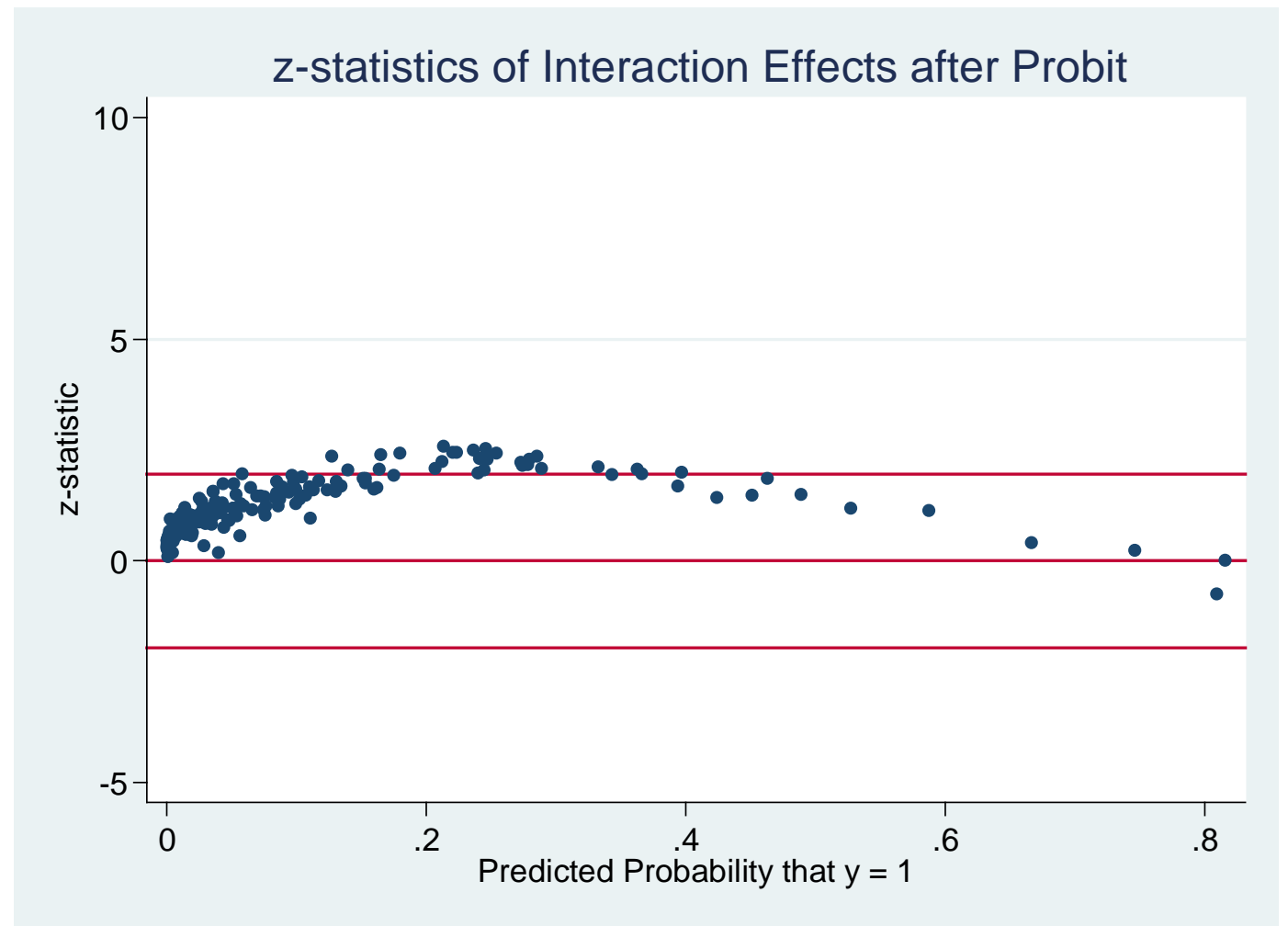

Legend. Z-statistics related to the marginal effect computed for the whole range of observations of the interaction variable Education $\times$ Work experience based on the estimates of the Probit model with clustered errors. 


\section{Appendix}

Table A1 - Founder human capital and probability of exit: elasticities and marginal effects

\begin{tabular}{lcc}
\hline \hline Model & $\begin{array}{c}\text { Probit } \\
\text { (clustered } \\
\text { errors, Table 5 } \\
\text { column III) }\end{array}$ & $\begin{array}{c}\text { Probit } \\
\text { (clustered } \\
\text { errors, Table 5 } \\
\text { column III) }\end{array}$ \\
\hline Variable & Elasticity & $\begin{array}{c}\text { (Average) } \\
\text { Marginal effect }\end{array}$ \\
\hline Education & $4.851(1.817)^{* * *}$ & $0.017(0.006)^{* * *}$ \\
Specific work experience & $0.480(0.144)^{* * *}$ & $0.007(0.002)^{* * *}$ \\
Generic work experience & $0.533(0.268)^{* *}$ & $0.004(0.002)^{*}$ \\
Managerial experience & $-0.409(0.186)^{* *}$ & $-0.161(0.062)^{* * *}$ \\
\hline \hline
\end{tabular}

Legend. Significance levels: *>10\%; ** $>5 \%$; ***>1\%. Marginal effects and elasticities of the human capital variables of interest based on Probit with clustered errors, reported in Table 5, column III. Standard errors computed with Delta method.

Table A2 - Founder human capital and probability of exit: the role of previous entrepreneurial experience

\begin{tabular}{|c|c|c|c|}
\hline & Columns & $\begin{array}{c}\text { Probit } \\
\text { (clustered } \\
\text { errors) } \\
1\end{array}$ & $\begin{array}{c}\text { Probit } \\
\text { (clustered } \\
\text { errors) } \\
\text { II }\end{array}$ \\
\hline & Dependent variable & Leave & Leave \\
\hline$a_{1}$ & Constant & $-4.650(1.639)^{* * *}$ & $-4.986(1.709)^{* * *}$ \\
\hline$a_{2}$ & Education & $0.122(0.051)^{* *}$ & $0.133(0.053)^{* *}$ \\
\hline$a_{3}$ & Work experience & $0.032(0.016)^{* *}$ & - \\
\hline$a_{4}$ & Specific work experience & - & $0.045(0.020)^{* *}$ \\
\hline$a_{5}$ & Generic work experience & - & $0.026(0.021)$ \\
\hline$a_{6}$ & Managerial experience & $-1.347(0.538)^{* *}$ & $-1.420(0.488)^{* * *}$ \\
\hline$a_{7}$ & Entrepreneurial experience & $0.290(0.402)$ & $0.265(0.393)$ \\
\hline$a_{8}$ & Share founder & $-0.008(0.011)$ & $-0.009(0.011)$ \\
\hline$a_{9}$ & Female & $-0.104(0.366)$ & $-0.089(0.363)$ \\
\hline$a_{10}$ & Founders & $0.251(0.186)$ & $0.273(0.183)$ \\
\hline$a_{11}$ & Size & $-0.073(0.223)$ & $-0.095(0.226)$ \\
\hline$a_{12}$ & Bank debt & $0.104(0.598)$ & $0.051(0.561)$ \\
\hline$a_{13}$ & $V C$ & $-0.119(0.524)$ & $-0.075(0.531)$ \\
\hline$a_{14}$ & Age & $-0.444(0.145)^{* * *}$ & $-0.448(0.147)^{* * *}$ \\
\hline$a_{15}$ & Internet & $0.423(0.465)$ & $0.439(0.460)$ \\
\hline$a_{16}$ & Infrastructure & $0.015(0.008)^{*}$ & $0.016(0.008)^{* *}$ \\
\hline$a_{17}$ & South & $0.926(0.770)$ & $0.941(0.786)$ \\
\hline$a_{18}$ & Centre & $-0.525(0.599)$ & $-0.518(0.609)$ \\
\hline \multirow[t]{5}{*}{$a_{19}$} & North-West & $-1.019(0.410)^{* *}$ & $-1.000(0.409)^{* *}$ \\
\hline & $N^{\circ}$ founders & 178 & 178 \\
\hline & $N^{\circ}$ of firms & 68 & 68 \\
\hline & Log-likelihood function & -39.746 & -39.566 \\
\hline & pseudo $R^{2}$ & 0.32 & 0.32 \\
\hline
\end{tabular}

Legend. Significance levels: *>10\%; ** >5\%; ***>1\%. 